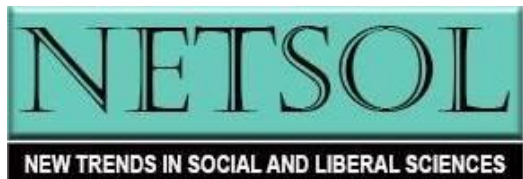

An Interdisciplinary Journal

http://www.netsoljournal.net/

Volume 2, Issue 2, pp.16-30, Fall 2017

https://doi.org/10.24819/netsol2017.07

\title{
Historiographical Perspectives of the Third Reich: Nazi Policies towards the Arab World and European Muslims
}

Jesus Montemayor

University of Texas Rio Grande Valley

\begin{abstract}
This historiographical essay examines major works on the interaction of Nazi Germany and the Arab World in general and the European Muslims in particular. The essay argues that despite the claims of revisionist studies that emerged after 9/11 terrorists attacks, the Nazi influence among the Arab and European Muslims was not deep enough to produce sufficient Muslim and Arab support for the Nazi cause.
\end{abstract}

Key Words: Third Reich, Nazi, Arab World, Islam, Middle East, Europe, Muslims, Historiography

When assessing the historiography of the Third Reich's efforts to garner allies in the Arab World and in southeastern Europe, readers may find minimal publications on the topic. In fact, since the end of World War II (WWII), only a limited number of scholars paid attention to this subject. However, after the September 11, 2001 terrorist attacks, there was a resurgence in the historiography inquiring about what influenced reactionary movements, such as al-Qaeda, ISIS, and Taliban and Hamas to commit such hostile acts against the Western World. This reawakening within the historiography has led some historians to reexamine Nazi Germany's Arab and Middle Eastern interactions and policies concerning the Islamic faith during WWII. The contemporary scholarship, in particular, has generated an interest in how the Third Reich appealed Islam to rally Muslims against Axis enemies and attempted to equate Nazism with the core principles of Islam. Though the Third Reich "presented themselves as friends to Muslims and defenders of the faith," Nazi Germany ultimately failed to garner enough Arab and Muslim support to turn the tide of the war. ${ }^{1}$

This historiographical study examines the scholarship on the Third Reich's foreign policies in the Arab and Muslim world. The essay analyzes historical arguments, scholarly disagreements, and primary and secondary sources, along with the development of the historiography on the subject from its conception in the 1950 s to the present. The selected texts provide readers with a comprehensive overview of the available scholarship, while at the same time, providing insight on how historians perceived the Third Reich's efforts to obtain political and military support in the Middle East, North Africa, and the Balkans and the Caucasus regions. The authors covered generally agree that the Nazis were unable to garner Arab and Muslim support during the later stages of the war; yet a common dilemma found within the historiography concerns the lack of available resources to reinforce historical claims. The sources used in the appraisals are, without a doubt,

${ }^{1}$ David Motadel, Islam and Nazi Germany's War (Cambridge: Belknap Press of Harvard University Press, 2014), 1.

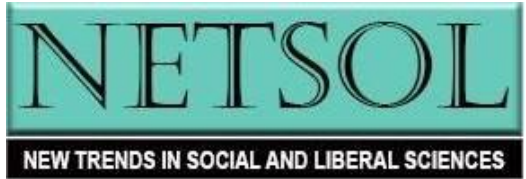


the focal point of the historiographical analysis. In addition to the issues discovered, some authors neglected the social histories of Arabs and Muslims within the Nazi occupied regions. This neglect of social histories was detrimental to the historiography since the earlier works did not present first-hand accounts on the occupied population. Historians who adhere to the Annales school of thought, however, have analyzed the historical memory of Arabs and Muslims under German occupation. As a result, the new historiographical contributions by scholars after 9/11 has generated new insights and inquiries concerning Germany's interactions with Arabs and Muslims. The scholarship presented has argued that the Nazi efforts to diffuse their influence in the Middle East was moderately successful before 1941 but several factors turned the trend backward. Economic and military limitations of Germany, its racist ideology, and Adolf Hitler's negligence towards the Middle East and North Africa, and German ignorance of Islam, along with the Haavara or the Transfer agreement, which strengthened the Zionist position over Palestine, and the implementation of Operation Barbarossa ultimately deterred Arabs and Muslims from supporting the Third Reich. $^{2}$

The historical discussions based on the war in Southwestern Asia first developed in 1952. George Kirk, a former Research Professor of International History at the University of London, provides a survey of international affairs primarily focusing on the Middle East during the war years from 1939 to 1946. His work not only focuses on the economic history and military campaigns of multiple countries, but also discusses the political motives of Arab and Islamic movements in North Africa and the Middle East. ${ }^{3}$ Kirk's analysis of Zionism, Arab nationalism, and Western European imperialism, and economic stagnation, provides readers with a foundation to understand Arab nationalist movements and Arabs opposition to Western European powers. Additionally, he sheds light on how the Nazis diffused their influence within the region; yet the dilemma with Kirk's assessment is his lack of focus and oversimplification of Germany's influence within the Middle East. In other words, he does not thoroughly examine Nazi ideological influence in the region, the effectiveness of propaganda, and how the Nazis attempted to use Islam to garner Axis support. Kirk's traditional top-down approach negates social histories of Arabs and Muslims affected by the war. His attempt to shed light on Nazi influence is simply a survey of the region during the war, and does not particularly concentrate on the Third Reich's ideological investment. Furthermore, reviewers of Kirk's book criticized his lack of effort to examine the broader context of the Middle Eastern experience during WWII. For example, Roderic Davison stated that Kirk "attempts no thorough examination of the spiritual crisis of the Middle East peoples, nor does he pull together the total impact of the war on thought and society," which suggests that the text provides a simplified summary of the Middle East and neglects the social histories of Arabs and Muslims altogether. ${ }^{4}$ The limited availability of primary resources at the time created a fundamental problem with Kirk's appraisal and, unfortunately, limited the scholarship about the Nazis in the Middle East. Kirk's book is significant to an extent since he not only produces further inquiries about the war's impact on Southwestern Asia, but he at least provides a foundation for future historians' work.

\footnotetext{
${ }^{2}$ Lukasz Hirszowicz, The Third Reich and the Arab East (London: Routledge and Kegan Paul, 1966), 309, 311, 315, 317. See also Motadel, Islam and Nazi Germany's War, 4-5, 321-322; Francis Nicosia, Nazi Germany and the Arab World (New York: Cambridge University Press, 2014), 278.

${ }^{3}$ George E. Kirk, The Middle East in the War 1939-1946: Survey of International Affairs (London: Oxford University Press, 1953), 3-4.

${ }^{4}$ Roderic H. Davison, “The Middle East in the War by George Kirk” The Journal of Modern History, Vol. 26, No. 4 (December 1954), 391.
}

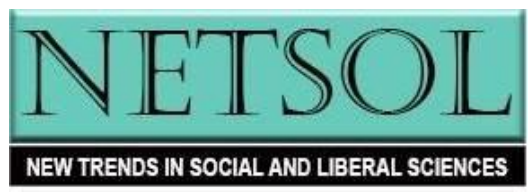


Lukasz Hirszowicz was the first notable historian who pioneered a concentrated study based on Nazi Germany's policies towards the Middle East and North Africa. ${ }^{5}$ In his appraisal, The Third Reich and the Arab East, Hirszowicz focuses on why Nazi opportunism in Southwestern Asia and North Africa failed to create a substantial collaboration with Arabs and Muslims. Hirszowicz clarifies why Germany was unsuccessful in garnering support; Germany was reluctant to intervene in North Africa in the late 1930s because they did not want to interfere in Italy's sphere of influence. Although there was a rising influence of Fascist organizations sympathized with Nazi ideals, especially the Misr el-Fatat (Green Shirts) in Egypt, the Germans "did not pay much attention to Arab aspirations" because Germany was focusing on gaining territory in Europe. ${ }^{6}$ Hirszowicz stated the region was of "secondary importance" to the Nazis, which demonstrates the region itself was of little importance to Hitler, until at least the Iraqi revolt on April 1, 1941, when Germany provided arms and funding to Arab nationalist Rashid Ali-al Kaylani's coup against a pro-British regime. ${ }^{7}$ Still, according to Hirszowicz, the Third Reich had "no elaborate military or political plans for Iraq" after the coup, which demonstrates Germany's unwillingness to interfere in the region. ${ }^{8}$ The analysis Hirszowicz provides fills the gaps in the historiography up to 1963. In contrast with Hirszowicz, Kirk did not thoroughly examine Nazi opportunism due to the limited availability of sources in 1952; instead, he argued Germany intervened in North Africa and the Middle East for strategic military purposes.

Hirszowicz focuses on the causes of Nazi Germany's failure establishing political alliances and strategic military positions in North Africa and the Middle East. He stresses that the Nazis had political and geographical barriers preventing Germany from taking advantage to obtain Arab support. Some examples Hirszowicz includes are the Arabs' "dislike for Fascist Italy's hegemony" in the region, Germany's failure to influence Saudi Arabian King Ibn Saud to side with the Nazis, and the presence of Allied forces in the region, and the geographical distance of Arab supporters from German assistance. ${ }^{9}$ Clearly, the mounting challenges and reluctance of intervention prevented Germany from gaining an upper hand in the war in North Africa and the Middle East.

Hirszowicz used diverse sources, such as archival materials from the German Democratic Republic, Nuremberg trial records, published collections, Arabian and European diaries, and existing secondary scholarship to support his claims throughout his appraisal. ${ }^{10}$ Because of the thorough use of primary and secondary sources, Majid Khadduri classified Hirszowicz's book as one of the first "serious studies of NaziArab relations." 11 Since Hirszowicz provides a "mine of information," future scholars could develop a comprehensive understanding on the Third Reich's policies towards the Arab World and the Middle East. ${ }^{12}$ Though Khadduri praised Hirszowicz's efforts, he criticized Hirszowicz for not "making an effort to interview" individuals who established relations between the Nazis and Arabs. ${ }^{13}$ Neglect of the Annales' school of thought, with the resulting lack of micro-historical study on ordinary Arabs and Muslims, was a common problem found within the earlier works. Inquiries concerning how people reacted to relations with the Nazis or reactions to propaganda could have helped readers to have a comprehensive outlook over

\footnotetext{
${ }^{5}$ Majid Khadduri, "The Third Reich and the Arab East by Lukasz Hirszowicz" The Middle East Journal, Vol. 21 , No.

3 (Summer 1967), 413.

${ }^{6}$ Hirszowicz, Third Reich and the Arab East, 13 and 33.

${ }^{7}$ Ibid., 42, 146.

${ }^{8}$ Ibid., 146.

${ }^{9}$ Ibid., 58, 60.

${ }^{10}$ Davidson, "Middle East in the War," 391; Hirszowicz, ix.

${ }^{11}$ Hirszowicz, Third Reich and the Arab East, ix; Khadduri, "Third Reich and the Arab East," 413.

${ }^{12}$ Hirszowicz, Third Reich and the Arab East, ix; Khadduri, "Third Reich and the Arab East," 413.

${ }^{13}$ Khadduri, "Third Reich and the Arab East," 413.
}

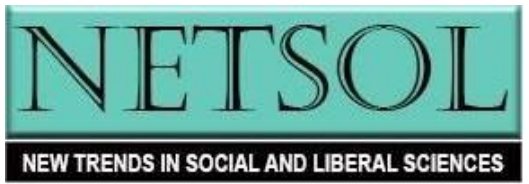


Germany's diplomatic relationships with Arab and Muslim states. Additionally, Hirszowicz disregards the effectiveness of Nazi policies and propaganda on these regions, which presents a minor problem in his text.

In comparison to Hirszowicz's claims, David Motadel and Jeffrey Herf both have similar arguments concerning the Arabic and Muslim views towards Italian imperialism. Hirszowicz argues that the Nazis did not want to intrude in North Africa and the Middle East since the region was under the auspices of Italian influence. ${ }^{14}$ Herf's appraisal concurs with Hirszowicz's argument since he argues the Nazis were careful not to offend, neglect, or marginalize Italy's influence in the region. ${ }^{15}$ Herf stated that the propaganda evolved towards gaining Arab and Muslim "hearts and minds" to join the Axis powers regardless of Italian hegemony, and rise against the Allies during the war. ${ }^{16}$ Moreover, Motadel raises similar arguments as Hirszowicz and Herf; he argues how the Nazis were careful to incorporate Islam into their policies and use the religion to garner Arab and Muslim support, while at the same time, respectively preserving and backing Italian hegemony in the region. ${ }^{17}$

Hirszowicz's appraisal was a groundbreaking contribution to the historiography of Nazi Middle Eastern and North African policies for using archival materials; yet, there was relatively little interest in the topic since 1966. ${ }^{18}$ Herf argued that the September 11, 2001 attacks renewed the relevance of Nazi policies towards the Middle East and saw an increase in the scholarship from 2001 to 2015. ${ }^{19}$ Additionally, Israel Gershoni clarified that after the 9/11 attacks, historians who were obsessed with the characterization of comparing global jihad to the concept of "Islamofascism," published appraisals in the early 2000s. ${ }^{20}$ According to Gershoni, the books published in the early 2000s connecting Nazism with Islamism did a disservice to the historiography. ${ }^{21}$ Some of the books published in the early 2000s include: Jihad and Jew Hatred: Nazism, Islamism and the Roots of $9 / 11$ by Mathias Küntzel and Crescent and Swastika: The Third Reich, The Arabs, and Palestine by German historians Klaus Michael Mallmann and Martin Cüppers. ${ }^{22}$

Küntzel shifted his research to analyze anti-Semitism and National Socialism influences in modern day Islam. Küntzel argues that, "In word and deed the Islamism of the first decade of the twenty-first century remains marked to this day by the connections with Nazism that emerged in the 1930s and 1940s." 23 In addition, he attempts to exhibit how the same anti-Semitic ideology the Nazis embraced spread to the Middle East, guided al-Qaeda and other reactionary movements. ${ }^{24}$ Küntzel focuses on the Grand Mufti of Jerusalem Haj Amin al-Husseini and his influence over diffusing anti-Jewish and anti-Zionist ideology in Palestine. According to Küntzel, the "successes" of the diffusion could be seen from not only the Mufti's collaboration with the Nazis, but also with Egyptian Muslim Brotherhood (MBH) leader Hassan al-Banna. ${ }^{25}$ Furthermore, al-Banna had great admiration for al-Husseini and was willing to support the anti-imperialist paramilitary groups against the Allies in Egypt. The connections Küntzel makes with the Mufti and his influence on al-Banna cannot be ignored simply because both men were seeing Nazism and Germany's

\footnotetext{
${ }^{14}$ Hirszowicz, Third Reich and the Arab East, 58-59.

15 Jeffrey Herf, Nazi Propaganda for the Arab World (New Haven: Yale University Press, 2009), 25-35.

16 Ibid., 13-14.

${ }^{17}$ Motadel, Islam and Nazi Germany's War, 17-19.

${ }^{18}$ Israel Gershoni, ed. Arab Responses to Fascism and Nazism: Attraction and Repulsion (Austin: University of

Texas Press, 2014), 5.

${ }^{19}$ Herf, Nazi Propaganda for the Arab World, 1.

${ }^{20}$ Gershoni, Arab Responses to Fascism, 26.

21 Ibid., 28.

${ }^{22}$ Herf, Nazi Propaganda for the Arab World, 1-2.

${ }^{23}$ Matthias Küntzel, Jihad and Jew-hatred: Islamism, Nazism and the roots of 9/11 (New York: Telos Press

Publication, 2007), xii.

${ }^{24}$ Ibid., xxiii.

${ }^{25}$ Ibid., 27-28 and 35.
}

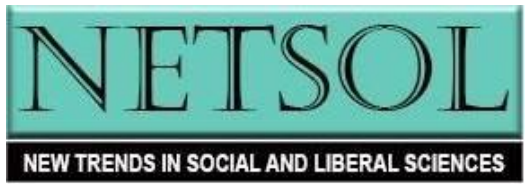


policies as similar to theirs. The Jewish immigrations to Palestine and Britain's Balfour Declaration ignited a reason for the two men to seek an alliance with the Nazis. This commonality of "hatred of the Jews was the most important shared bond," which further fueled reactionary movements to oppose Western support of the Jewish state. ${ }^{26}$

In response to Küntzel's appraisal, Gershoni argues that Küntzel was lacking credible evidence and seemed to compel scholars to believe the Nazis initially influenced global jihadism. ${ }^{27}$ This is an accurate statement by Gershoni because in his conclusion Küntzel goes on a tangent advocating Western political correctness fails "to recognize the substance of Islamist ideology - the death cult, anti-Semitism and hatred of freedom - we will again and again end up discovering the sole root cause of terrorism" and violence in the region. ${ }^{28}$ Küntzel does not fall back on how the Nazis influenced the modern day reactionary movements; the brief mention of Nazism's commonality of hatred of the Jews to Islamism was not conclusive enough to support his claims. An example of Küntzel's generalization regards the creation of the Syrian Baath Party. He quotes Sami al-Jundi, a leader of the Syrian Baathist Party, about how the party was influenced by philosophers Friedrich Nietzsche, Johann Gottlieb Fichte, and H.S. Chamberlain, while claiming "we were the first to think of translating Mein Kampf" into Arabic. ${ }^{29}$ Although Küntzel makes an effort to inform his readers about the influence of Nazi ideology on reactionary movements, his analysis lacks a detailed account of how Nazism inspired the creation of the Baath Party. Moreover, Küntzel's book seemed to read as a rant against Islam and did not provide enough thorough analysis over the connections Nazism had with Islamism. "At best," stated Gershoni, Küntzel's book "was a stretch and at worst forced" upon his readers to adhere to his unconvincing arguments that lacked credible evidence. ${ }^{30}$ Küntzel's biased account does more harm than good for the historiography; he neglects that even before the rise of the Third Reich, tensions among the Jews and Muslims were prevalent within the holy land of Jerusalem. How can readers expect to adhere to Küntzel's arguments when he chooses only topics, which lend credit to his overall argument? The clear bias in his writing does not provide a balanced approach in how the Nazis influenced modern day reactionary movements.

In response to the early 2000s publications, Francis R. Nicosia published Nazi Germany and the Arab World, which analyzes Germany's involvement with North African and Middle Eastern nationalists and anti-imperialist movements. His thesis argues that the Nazis, Arabs, and Muslims were ideologically incompatible from the start and destined not to generate mutual relations. ${ }^{31}$ His argument is important because Nicosia is straying away from the arguments linking Nazism with Arabism and political Islam. Nicosia's publication contributes to the historiography of Nazi relations in North Africa and the Middle East and academically eases the damage caused by the appraisals published in the early 2000s. Nicosia backs away from Motadel's and Gershoni's bottom-up methodologies but rather he reexamines Kirk's and Hirszowicz's approach by basing his study from a top-down perspective.

A commonality found in Nicosia's and Hirszowicz's appraisals was their arguments concerning Nazi negligence towards the Arab and Muslim world. Hirszowicz emphasized German ineffectiveness on waging war in the Arab World and their inability to send supplies to pro-Axis supporters in the region after $1941 .^{32}$ Operation Barbarossa, the invasion of the Soviet Union that began in June of that year, created a critical dilemma and essentially marked the turning point for German-Arab relations. German forces, especially in

26 Ibid., 59-60.

${ }^{27}$ Gershoni, Arab Responses to Fascism, 26-28.

${ }^{28}$ Küntzel, Jihad and Jew-hatred, 159.

${ }^{29}$ Ibid., 26.

${ }^{30}$ Gershoni, Arab Responses to Fascism, 28.

${ }^{31}$ Nicosia, Nazi Germany and the Arab World, 13.

${ }^{32}$ Hirszowicz, 193.

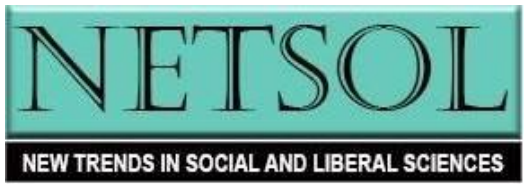


North Africa, were deprived of arms and repairs to tanks because most of Germany's supplies went to the Eastern Front to attack the Soviets. ${ }^{33}$ In other words, Germany's war interests in Europe were more significant than the Arab and Muslim world. Nicosia points out that Germany also had to worry about the imperial ambitions of Italy. ${ }^{34}$ A comparison of Hirszowicz's and Nicosia's work demonstrates the importance of old scholarship from 1966 to the revisionists in the early 2000s; their top-down approaches detailed how and why the Nazis neglected the region.

Nonetheless, the inclusion of Küntzel's, Mallmann's, and Cüppers, texts in Motadel's, Nicosia's, Herf's, and Gershoni's bibliographies displays the evolving progress and importance of their contributions to the historiography. ${ }^{35}$ Though the revisionist 2000s publications were informative, and at times, misrepresented information, the increasing interest in the historiography was keen to introduce the Annales school of thought in the topic. Ultimately, one must ask how has the Annales methodology changed the dynamics of the historiography today?

Motadel represents the Annales school of thought since his scholarship shifts away from stigmatizing the Nazi regime and Arabs and Muslim collaborators. In Motadel's text, Islam and Nazi Germany's War, he bases his research on available archival sources, contemporary books, articles, and memoirs. Unlike Hirszowicz, Motadel uses the Nuremberg interrogation transcripts, military orders, and documents from non-German archives to enhance the effectiveness of his research and thesis ${ }^{36} \mathrm{He}$ pulls sources from a variety of archives, including the British Naval Archives, United States National Archives, and Vienna City and State Archive, Czech Central Military Archives, and Russian State Military Archives, Latvian State Historical Archive, and the Archive of the Historical Museum of Bosnia and Herzegovina, Albanian Central State Archives, and the Iranian National Archives. ${ }^{37}$ Through the works of Hirszowicz and Motadel, readers can observe a shift of focus from the political, ideological, and military perspective to social histories. Motadel refrains from taking a top-down approach and instead, bases his works on a bottom-up perspective by examining how Nazi Germany utilized Islam in its policies to garner support in the North Africa, the Middle East, the Balkans, and the Caucasus region.

Additionally, Motadel focuses on the effectiveness of Berlin's "religiously charged propaganda" campaign against the Allies and the shared ideological resentment Arabs, Muslims, and Nazis had against Slavs and Jews. ${ }^{38}$ In particular, Motadel displays how easy the effort was to influence the Muslims to join and fight against the Soviets. He provides numerous examples as to how Soviet repression towards Islamic culture helped the Nazi cause to easily recruit Muslims and generate a favorable response to fight against the Soviet Union. ${ }^{39}$ In contrast to how the Soviets treated Muslims, the Nazis treated Islam and Muslims with respect in an effort to legitimize Germany's authority over the Middle East. Motadel stated, "Muslims were not seen as threats or enemies but as powerful allies" in the war zones for the Nazi regime. ${ }^{40}$

Although the Nazis used propaganda to fuel their campaign in the Middle East, there were many obstacles, which ultimately deterred Muslims from supporting the Nazis, such as high illiteracy rates, impoverished populations not owning radios, and inadequate infrastructure, and Allied censorship. ${ }^{41}$ In

\footnotetext{
${ }^{33}$ Ibid., 193, 203.

34 Nicosia, 265.

${ }^{35}$ Nicosia, Nazi Germany and the Arab World, 288; Motadel, Islam and Nazi Germany's War, 343, 353; Gershoni, Arab Responses to Fascism, 351-352.

${ }^{36}$ Motadel, Islam and Nazi Germany's War, 325-326.

${ }^{37}$ Ibid., 326.

38 Ibid., 73.

${ }^{39}$ Ibid., 76-80.

${ }^{40}$ Ibid., 315.

${ }^{41}$ Ibid., 107-108, 136.
}

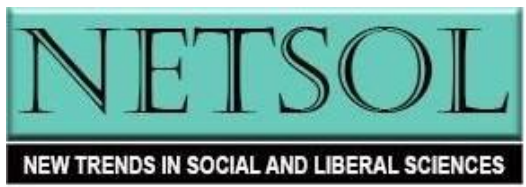


addition to the Third Reich's failed attempts to garner support, the Germans, at times, did not fully comprehend the Islamic religion. Motadel's article "Islam and Germany's War in the Soviet Borderlands, 1941-1945" gives an example of German ignorance of Islam: German SS soldiers in the early months of the Barbarossa Campaign executed circumcised Muslim prisoners in the occupied areas assuming that they were Jews. ${ }^{42}$ Gestapo officer Heinrich Müller did not know "Muslims too were circumcised." ${ }^{43}$ Motadel's micro-approach helps readers to have a "total history" perspective of the circumstances about Nazi Germany's Islamic policies, especially in the Soviet Borderlands.

The available sources, especially from Motadel's bibliography, allow readers to develop a comprehensive understanding of how Nazi Germany attempted to rally Muslims against Allied powers. Robert F. Baumann stated that, "Motadel's study includes much original research and pulls together in a coherent narrative the separate experiences of a variety of Muslim populations" and is a valuable contribution to scholarship of WWII. ${ }^{44}$ Not only did Motadel excel in using diverse resources, but also he dynamically shifted the focus of historiography from Arab and Muslim experiences with Nazi occupation and policies, to the Nazis utilization of religion as a means to garner Axis support. Motadel's shifting of focus was possible because of available resources and contemporary publications. Especially the primary sources accessible after the Cold War has allowed the historiography to evolve and develop into a comprehensive topic, while at the same time, helping historians to engage further inquiry and research about the Nazi influence on the Arab and Muslim world.

Motadel's research and publications have had a profound impact on the methodological approaches and scholarship of Nazi Germany's war in the Arab World. He argues that the Nazis' attempt to use Islam for geopolitical and ideological means was keen to garner Arab and Muslim support for the Axis powers. Unlike Hirszowicz and Kirk, in his work, Islam and Nazi Germany's War, Motadel emphasizes the significance of religious values on Germany's policy decisions. In other words, the Nazis used Islam and were selective in choosing what Qur'anic interpretations would benefit Germany politically and militarily. ${ }^{45}$ Motadel's methodology, especially his analysis on Islamic mobilization, is unique; no other work before Motadel had "attempted to put Islam on a political and strategic map of WWII," which demonstrates the significance of his work. ${ }^{46} \mathrm{He}$ claims the scholarship of "Nazi Germany's policy toward Islam is ideal for studying the politics of the religion as an instrument in world politics and military conflict." ${ }^{\text {47 }}$ Motadel's claims assist historians to generate interest in whether Nazism's influence was profound or not. Motadel's thesis argues that, "[r]eligion is seen as a source of authority that can legitimize involvement in a conflict and even justify violence" against the Allied powers. ${ }^{48}$ The Nazis took the opportunity to use Islam against the Allies for political, geographical, economic, and military gains; however, the complexities of the Islamic culture, ineffectiveness of Nazi policies, along with Germany's ignorance of Islamic customs and beliefs, ultimately did not generate a successful campaign for Nazi Germany in the Middle East.

Motadel separates his text into three units; the foundations of Islamic policies, the Muslims in war zones, and the Muslims in the German military. Motadel's method of examining the history of Germany's Islam policy is unique since not many authors have investigated Germany's Islam and the Middle East

\footnotetext{
42 David Motadel, “Islam and Germany's War in the Soviet Borderlands, 1941-1945” Journal of Contemporary History, Vol. 48, No. 4 (October 2013), 815.

${ }^{43}$ Ibid., 815.

${ }^{44}$ Robert F. Baumann, “Islam and Nazi Germany’s War” Military Review, Vol. 96, No. 4 (July 2016), 138.

${ }^{45}$ Motadel, Islam and Nazi Germany's War, 68-70.

${ }^{46}$ Ibid., 5.

${ }^{47}$ Ibid., 10.

${ }^{48}$ Ibid., 9 and 321-322.
}

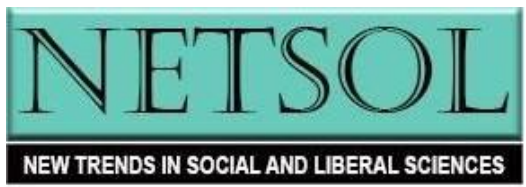


policies in the nineteenth century, especially in Africa. His narrative helps readers grasp the German policies toward Islam before the outset of WWII and exhibits that the Third Reich's policies were not necessarily unique, but reminiscent of policies imposed by Imperial Germany in the nineteenth century. In particular, Motadel examines Imperial Germany's territories in Sub-Sahara Africa and concentrates on how the Germans maintained control over their colonial possessions; Germany tolerated Islamic customs and left Islamic structures intact to preserve order and hegemony in Muslim territories. ${ }^{49}$ Motadel emphasizes his argument by claiming, "Islam seemed to offer a comprehensible religious code that non-Muslim authorities could decode and exploit for political aims" and military purposes. ${ }^{50}$

Motadel continuously reinstates his argument that Germany used Islam to bolster "authority" to "guarantee stability" and influence Muslims to wage jihad against Germany's enemies. ${ }^{51}$ He provides historical examples, such as the sympathetic treatment Muslim POW's received during the Great War, an anti-imperialist stance directed against France and Britain, at least in terms of propaganda. Motadel explains that despite minor successes, the Germans were unsuccessful in utilizing Islam to further their agenda, such as convincing Muslims to wage jihad against Britain and France, because Germans did not completely grasped the principles of Islam.

Motadel avoids providing readers with a top-down analysis and delivers an Annales approach for readers to comprehend Muslim point of view under Nazi occupation. In contrast to Hirszowicz's and Kirk's arguments, Motadel deviates away from focusing primarily on the Nazi regimes policies and administrative reactions; instead, he provides a thorough outlook on how the Nazis influenced the change in culture, customs, and ideology in the German occupied regions. Hirszowicz and Kirk did not provide much detail on the cultural reactions to Nazi policies, which had been missing in the historiography until Motadel's and Herf's publications. Motadel relied on primary sources to narrate a "total history" of peoples affected by the Third Reich's Islamic policies. Arnold Krammer classified Motadel's appraisal as an "important book with a different view of the World War, superbly researched, and elegantly produced," which proposes the historiographical significance of the text itself. ${ }^{52}$

Motadel's analysis over the historical memory of Muslims is important because of the contribution social histories made on the historiography of Nazi Germany's interventions. He excels in adding a dynamic and crucial part of the Second World War, while at the same time, inquiring how the major powers, especially Germany, engaged Islam for political means. ${ }^{53}$ Motadel's article "Islam and Germany's War in the Soviet Borderlands, 1941-1945" focuses on how the Nazis saw the opportunity to use Islam as a political and strategic advantage to counter Soviet influence in the Caucasus regions. This was not only a counter measure, according to Motadel, but was a policy to persuade Muslims that the Nazis were the "liberators" from the Soviet suppression in the region. ${ }^{54}$ Herf's work Nazi Propaganda for the Arab World reaches to the same conclusion as Motadel. Both posited that the Nazis propaganda campaign exhibited Germans as the "liberators" from the British and French colonialism and imperialism in the Middle East and North Africa. ${ }^{55}$ Motadel's article focuses on social histories where he informs how the enforcement of Nazi policies changed Muslims' perspectives of the Nazis, whereas Herf centers his argument on how the Nazis changed their policies to adopt anti-Zionist and anti-Semitic values to garner Muslim support.

\footnotetext{
49 Ibid., 16-17.

${ }^{50}$ Ibid., 8 and 322.

51 Ibid., 17-19.

52 Arnold Krammer, “Islam and Nazi Germany’s War” Journal of Military History, Vol. 79, No. 2 (April 2015), 521.

${ }^{53}$ Motadel, “Islam and Germany's War in the Soviet Borderlands, 1941-1945”, 784.

${ }^{54}$ Ibid., 784,-788.

55 Herf, Nazi Propaganda for the Arab World, 3, 45-46.
}

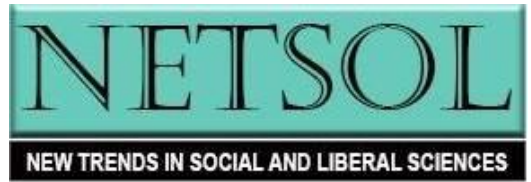


Motadel's article concerning Germany's Islam policies in the Soviet borderlands helps readers to compare Muslim reactions to Nazi occupation versus Soviet occupation. Motadel sets the tone of the article by examining how the Bolsheviks treated Muslims in the region and emphasizes how the Soviet authorities saw Islamic areas as subversive and enforced "unprecedented religious persecution." as the "destruction of mosques, abolition of Shari"a, the persecution of the 'ulama," and the ridiculing of Islamic customs and architecture, demonstrates how discriminatory and violently repressive the Soviet regime was.$^{57}$ Clearly, the Nazis saw an opportunity to diffuse their influence and mold their ideology to coincide with Islamic ideals. The only downside with the historiography is the limited number of works on the Soviet repression of Muslim communities in the Caucasus region. Yet, Motadel provides a glimpse of how Muslims viewed the Soviet suppression of religion. Motadel's micro-historical perspective details why Muslims saw the Nazis as liberators from the Soviet oppression.

In addition to Motadel's historiographical contributions, his article "The Muslim Question in Hitler's Balkans" further broadens the historiography of WWII in Southeastern Europe. In particular, Motadel's recurring method of using social histories to emphasize his thesis is visible throughout the article. His central thesis posits that, "[r]eligion could be crucial - and at time even more important than ethnic and racial categories - for German political and military officials when drafting policies towards them." ${ }^{58}$ The Nazis' efforts to instrumentalize Islam in the Balkans, especially in Yugoslavia, had a far more drastic effect in comparison to Germany's occupation of the Caucasus region. Motadel evaluated the history of ethnic and religious tensions among the Yugoslavs and other Balkan countries. The diversity of the region created a quagmire for the Nazis since Serbs, Croats, and Bosnians all had different national identities and were more concerned for consolidating power to create their own nation-state. ${ }^{59}$ Though the conflict in the Balkans was extensive and dynamic, the Nazis inevitably used Islam for political purposes to influence the population of the region and to present Germany as a collaborator rather than an enemy. Germany's exertion of influence created a sense of national identity among Muslims, which resulted in insurgencies to counter Josip Broz Tito's Communist surge in the region. ${ }^{60}$ Motadel summarizes that in propaganda the Nazis' appealed not only to a religious rhetoric, but also religious dignitaries to garner German support from the Muslims and to accentuate the Third Reich's role as the patron of Islam. ${ }^{61}$

Several historians have disagreements on whether or not the Grand Mufti of Jerusalem Haj Amin alHusseini had any role on the decision-making of Final Solution. In Barry Rubin's and Wolfgang Schwanitz's appraisal Nazis, Islamists, and the Making of The Modern Middle East, they describe alHusseini as "The single most important foreign collaborator with the Nazis and certainly the most prized non-European." ${ }^{62}$ The Grand Mufti was an Arab nationalist and an admirer of Hitler; he claimed, "Germany was a natural friend" since Britain and the Jews were common enemies. ${ }^{63}$ The collaboration al-Husseini had with the Third Reich was unique since he was a Muslim, who attempted to garner and advocate for political and militant support for the Nazis in North Africa and the Middle East. Rubin and Schwanitz suggest al-Husseini's influence on Nazi Germany was more significant than historians realize. For instance, they suggest the Mufti's meeting with Hitler on November 28, 1941, influenced Hitler to send out

\footnotetext{
${ }^{56}$ Motadel, "Islam and Germany's War in the Soviet Borderlands, 1941-1945", 786.

${ }^{57}$ Ibid., 786-787.

${ }^{58}$ David Motadel, “The Muslim Question in Hitler's Balkans” The Historical Journal, Vol. 56, No.4 (2013), 1039.

${ }^{59}$ Ibid., 1017.

${ }^{60}$ Ibid., 1016-1017.

${ }^{61}$ Ibid., 1017.

${ }^{62}$ Barry M. Rubin and Wolfgang G. Schwanitz, Nazis, Islamists, and the Making of the Modern Middle East (New Haven: Yale Univ. Press, 2014), 176.

${ }^{63}$ Ibid., 7.
}

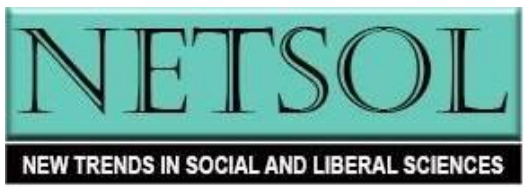


invitations to high-ranking Nazi officials for the Wannsee Conference, which is widely known by historians as the meeting where German officials orchestrated the Final Solution of the European Jews. Historians Jeffrey Herf and Christopher Browning challenged the claim that the Mufti influenced the Nazis' Final Solution since both argued Hitler was already fixated on the idea of exterminating the Jews. Herf, in particular, downplays al-Husseini's role in the Final Solution decision-making stating the Mufti's "collaboration was both a matter of shared political interests as well as ideological" commonalities, nothing more.$^{64}$ This indicates al-Husseini did not have a keen role in the decision-making process. Herf emphasizes his point by stating, "The name Haj Amin al-Husseini does not come up at all in his [Hitler's] account simply because the Mufti was not in the chain of decision-making of the German government." 65 Herf cautions readers not to fall for the sensationalism of the Mufti's role in the Third Reich. He states that, "They [Rubin and Schwanitz] turn a series of coincidental correlations in time into causal chains." 66 The Mufti may have had a key role in diffusing anti-Jewish propaganda in North Africa and the Middle East, but at best, al-Husseini's role in the Final Decision planning was relatively non-existent. Rubin's and Schwanitz's text provides an insightful account of the Mufti, yet, their text overall provides vague conclusions and attempts to connect his influence to the rise of reactionary movements in the Middle East today.

Not many scholars have had keen interest in analyzing the historiography of Fascist and Nazi ideological reactions in the Middle East and North Africa. Israel Gershoni has given insight on how Arabic populations interacted with these particular ideologies. Gershoni's efforts to compile essays broadened the field, while providing a new understanding of how complex and critical the analysis of ideological reactions is to the historiography. ${ }^{67} \mathrm{In}$ its analysis of the historiography of Nazi relations with the Arab and Muslim world, the compiled book covers how Syrian, Lebanese, and Palestinian, Iraqi, and Egyptian, and Ethiopian people reacted to Fascist and Nazi ideology. The essays are extensive and contribute to the historiography of the subject since this is one of the first appraisals to present an overview of how the changing dynamics of ideology during the war affected Arabs and Muslims. Gershoni's contribution has given insight to readers who are seeking to learn more about how Nazism and Fascism affected the North Africa and the Middle East.

Written under the guidance of Annales school of thought, Herf's book Nazi Propaganda for the Arab World stresses different strategies implemented by Germany to gain political allies through propaganda. The campaigns in North Africa and the Middle East presented the opportunity for the Nazis to gain allies and diffuse their hegemony in the region. Herf presents a chronological timeframe from the evolution of Nazi propaganda to ultimately the desperate attempts to seek Arab and Muslim support towards the end of WWII. He argues that the "Nazi leadership equated National Socialism to extreme anti-Semitism and antiZionism" in an effort to win over the hearts and minds of Arabs and Muslims. ${ }^{68}$ Herf centralizes key parts of his book on the Palestinian issue and he thoroughly gives readers insight on how Germany attempted to exploit the Palestinian conflict with propaganda to garner support for the Nazi regime. He explains that acquiring Arab trust was not easy for Germany, especially after the Haavara or the Transfer Agreement. Palestinian Arabs were less sympathetic towards Germany's cause since the Haavara Agreement allowed for the emigration of German Jews to Palestine. This was the first instance when Nazi officials and German Jews collaborated; a minimum payment of a thousand pounds was required to allow Jewish migration and

\footnotetext{
64 Jeffrey Herf, "Haj Amin al-Husseini, the Nazis and the Holocaust: The Origins, Nature and After Effects of Collaboration," Jewish Political Studies Review, Vol. 26, No. 3 (Fall 2014), 18.

${ }^{65}$ Ibid., 23.

${ }^{66}$ Ibid., 24.

${ }^{67}$ Gershoni, Arab Responses to Fascism, xi.

${ }^{68}$ Herf, Nazi Propaganda for the Arab World, 13-14.
}

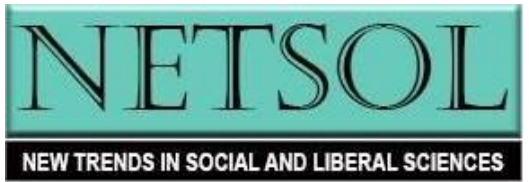


the transfer of Jewish capital to Palestine between 1934 and $1937 .{ }^{69}$ In turn, the agreement presented an opportunity for the Jews to arrive in Palestine "not as have-nots, but as owners of their capital." ${ }^{\text {" T0 }}$ The Jewish colonization and economic control of Palestine became possible because of the Haavara Agreement, thus setting the stage for conflict against Palestinian Arabs and Muslims between 1936 and 1939. The Haavara Agreement, according to Herf, "hastened the formation of a Jewish state, and could contribute to the view that Germany supported the formation of a Jewish state in Palestine." "71 Herf states that German interests during WWII changed; the Haavara agreement ceased to exist and strategic military interests became priority. As a result, "strengthening of Arabs as a counterweight to any such expansion of Jewry power" was imperative to win the war. ${ }^{72}$

Küntzel did not even mention the Haavara Agreement. Herf, Nicosia, and Motadel argue that the collaboration between the Nazis and German Jews essentially set the stage for the creation of a Jewish state. Küntzel's arguments concerning Nazi influence is not as cohesive as one may think since Nazi and Jewish collaboration demonstrated Germany's ability to modify its policy in an effort to improve German interests; Arab interests, especially Palestinian Arabs, were not important. German policy to make Palestine a destination for German Jews was in place until 1937; yet the Arab outrage in the Middle East and North Africa, along with the shifting European politics in 1938-1939 forced Germany to refocus and change its policy.

The initial chapters of Herf's appraisal center on the Nazi definition of anti-Semitism and inquire as to what classifies a master "Aryan race." The publication of Mein Kampf, nonetheless, provided Adolf Hitler's entailment of the "Aryan race" and emphasized the inferiority of all non-Aryan individuals. ${ }^{73}$ According to Herf, the citizenship decrees in the mid-1930s not only deprived Jews off their basic civil liberties, but also emphasized a "Eurocentric" perspective on race, which antagonized all non-German races. ${ }^{74}$ The Nazis' "Eurocentric" anti-Semitism was hostile and offensive against all Arabs and Muslims, and it created a quagmire concerning Nazi relations with the Arab World. This stands out in Herf's text because in his work Motadel posited that Nazis modified their Eurocentric policies to fit the mold of the Arab race. Herf, in particular, provides vivid details as to how the Nazis attempted to curtail their definition of anti-Semitism and refocus the target of the word specifically to antagonize the Jewish race. ${ }^{75}$ Some examples include a revised publication of Mein Kampf, which removed offensive passages towards Arabs and Muslims; the modification of Hitler's speeches to be less offensive towards the Arab World, and the use of propaganda to promote not only unity among Germany and the Arab World, but to showcase Nazi support for anti-Zionism. ${ }^{76}$ Herf's analysis helps readers understand that Germans were willing to do anything, even contradict their own ideology to gain the "hearts and minds" of the Arab World.

Herf gives more details about the evolution of Nazi propaganda during WWII. In particular, he focuses on how the Nazis constantly compared National Socialism with Islam. The Nazi propaganda attempted to align Nazism and Islam on anti-Semitism and anti-Zionism against the Jews and Allies. According to Herf, the Nazis over emphasized their anti-Zionist stance and propagated pamphlets to depict

\footnotetext{
${ }^{69}$ Klaus Polkehn, “The Secret Contacts: Zionism and Nazi Germany, 1933-1941” Journal of Palestine Studies, Vol. 5, No. 3/4, (Spring-Summer, 1976), 66.

${ }^{70}$ Ibid., 66.

${ }^{71}$ Herf, Nazi Propaganda for the Arab World, 29.

72 Ibid., 28.

73 Ibid., 21-23.

74 Ibid., 21.

75 Ibid., 23, 35.

${ }^{76}$ Ibid., 25-26, 30-35.
}

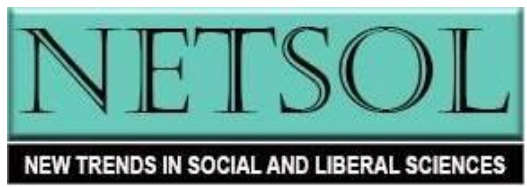


the Allies as supporters of Zionism. ${ }^{77}$ Although Herf explains the Allies did not directly support Zionism, in their propaganda the Nazis fore fronted the Balfour Declaration of 1917 and the British mandate of Palestine to display the Allies' support for Zionism. ${ }^{78}$ Some of the propaganda statement examples Herf provides are quite obscene and surreal to contemplate since the phrasing used in radio transmissions, for example, "urged Arab and Muslim listeners to take matters into their own hands and kill every Jew in North Africa and the Middle East themselves." ${ }^{\prime 79}$ The Nazi propaganda efforts were partially effective, especially in Egypt, Iraq, and among the exiled Arabs in Germany. Herf stresses that the propaganda had a tremendous influence on diffusing Nazism and Islam collaboration throughout North Africa and the Middle East. In addition, leaders such as the Muslim Brotherhood's Hassan al-Banna, al-Husseini, and the leader of the 1941 Iraqi coup d'état Rashid Ali Al-Gaylani were anti-Jewish collaborators and fully supported the Nazi stance of anti-Zionism. ${ }^{80}$ The efficiency of propaganda, especially when the Nazis used selective excerpts from the Qur'an, generated support and displayed how German and Muslim cultures influenced and altered the ideological frameworks. ${ }^{81}$

\section{Conclusion}

The historiography of Nazi relations with the Arab World and European Muslims has become an interestingly growing topic within the spectrum of WWII. Historians of the 1950s did not adequately cover the relationship between Germany and the Arab World and European Muslims or the policies implemented by the Third Reich on the Middle East and Islam. The majority of the literature primarily concentrated on the administrative, political, and economic outlook Germany had in North Africa, the Middle East, and the Balkans in general. There was limited scholarly attention on Germany's Middle East and North Africa policies during the war until Hirszowicz published his work in 1966. Hirszowicz analyzed Germany's relations from a top-down, military, and political perspective; he assessed administrative decisions and the impact of these decisions on the regions. He presented that Germany did not see the Arab World as a primary objective; rather the region was of secondary importance. Additionally, he stresses that the Nazis were more interested in preserving Europe and they viewed other regions as colonial possessions. Nazis had little to no interest in backing up Arab nationalist movements to form nation-states or to preserve Palestine for Arabs. Although Germany failed to generate a coherent alliance with Arabs and Muslims, the Nazis, indeed, had a significant influence over the region. These early works provided a foundation for the historiography of the topic. Though the works had minor flaws and were limited in using resources, the analysis and scholarship paved the way for the Annales historians to generate a comprehensive overview of Nazi interactions with the Arab World and European Muslims.

The Annales historians reevaluated and reshaped the way scholars conduct research on the Third Reich's policies in North Africa and the Middle East. Appraisals from the early 2000s, such as Küntzel's text invoked Islamophobic rhetoric, which does not lend credibility to his appraisal whatsoever. To counter Küntzel's revisionist argument of equating Islam and Nazism, the Annales historians, who include Rubin, Schwanitz, and Motadel, Herf, and Nicosia, and Gershoni, contributed to the creation of a micro-history covering individuals under German occupation. The Annales approach gave scholars an opportunity to examine how the Nazi interpretation of Islam influenced the occupied regions, and how Nazis utilized propaganda, ideology, and social interactions to gain allies. In the past, historians neglected micro-history;

77 Ibid., 87.

${ }^{78}$ Ibid., 86-87, 100.

79 Ibid., 89.

${ }^{80}$ Ibid., 121-122, 168-169,

${ }^{81}$ Ibid., 266.

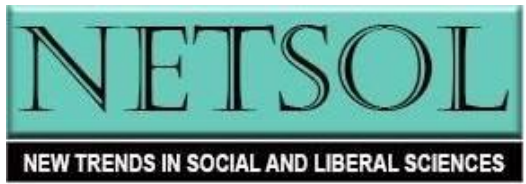


yet, the Annales historians have now provided more insight and narrowed a historiographical gap within the topic itself.

The Annales works have contributed to improving the historiography of WWII. They not only strayed away from the literature producing sensationalism and Islamophobic rhetoric in the early 2000s, but they create quality works for readers and scholars alike. Because of their efforts, the historiography has provided a foundation for more research and scholarship. The Annales methodology has prevailed in providing a total history narrative of the Third Reich's policies towards the Arab World and European Muslims. Although historiographic gaps remain, there is no doubt Germany's collapse left behind a legacy of influence in ideology, racism, anti-Jewish sentiment, and anti-Zionism. By reading the appraisals selected for this historiographical paper, one may conclude the Nazis had far more complex plans for the Middle East and North Africa than expected.

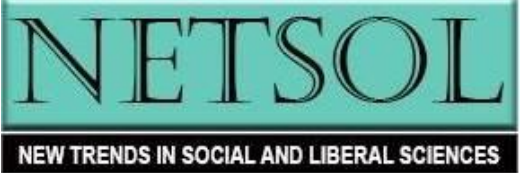




\section{Bibliography}

\section{$\underline{\text { Books }}$}

Gershoni, Israel. ed. Arab Responses to Fascism and Nazism: Attraction and Repulsion. Austin: University of Texas Press, 2014.

Herf, Jeffrey. Nazi Propaganda for the Arab World. New Haven, CT: Yale University Press, 2010.

Hirszowicz, Lukasz. The Third Reich and the Arab East. London: Routledge \& K. Paul, 1966.

Kirk, George E. The Middle East in the War (Survey of International Affairs, 1939-1946). London: Oxford University Press, Issued under the Auspices of the Royal Institute of International Affairs, 1954.

Küntzel, Matthias. Jihad and Jew-hatred: Islamism, Nazism and the Roots of 9/11. New York: Telos Press Pub., 2007.

Motadel, David. Islam and Nazi Germany's War. Cambridge: Belknap Press of Harvard University Press, 2014.

Nicosia, Francis R. Nazi Germany and the Arab World. New York: Cambridge University Press, 2014.

Rubin, Barry M., and Wolfgang G. Schwanitz. Nazis, Islamists, and the Making of the Modern Middle East. New Haven: Yale University Press, 2014.

Sayegh, Sharlene and Altice, Eric. History and Theory. Boston, MA: Pearson, 2014.

\section{$\underline{\text { Academic Journals }}$}

Herf, Jeffrey. "Haj Amin al-Husseini, the Nazis and the Holocaust: The Origins, Nature and After Effects of Collaboration." Jewish Political Studies Review, Vol. 26/3 (2014): 13-37.

--“Nazi Germany's Propaganda Aimed at Arabs and Muslims During World War II and the Holocaust: Old Themes, New Archival Findings." Central European History, Vol. 42/4, (2009): 709-736.

Motadel, David. “Islam and Germany's War in Soviet Borderlands, 1941-1945.” Journal of Contemporary History, Vol 48/4 (October 2013): 784-820.

--_The Muslim Question in Hitler's Balkans.” The Historical Journal, Vol. 56/4 (2013): 1007 1039.

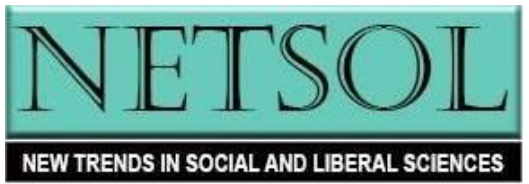


-------- “Muslims in Hitler's War.” History Today, (September 2015): 19-25.

Polkehn, Klaus, “The Secret Contacts: Zionism and Nazi Germany, 1933-1941.” Journal of Palestine Studies, Vol.5/3-4, (1976): 55-82.

\section{Book Reviews}

Baumann, Robert F. “Islam and Nazi Germany's War.” Military Review, Vol. 96/4 (July/August, 2016), 138.

Davidson, Roderic H. "The Middle East in the War by George Kirk" The Journal of Modern History, Vol. 26/4 (December 1954): 390-391.

Khadduri, Majid. "The Third Reich and the Arab East by Lukasz Hirszowicz." The Middle East Journal, Vol. 21/3 (Summer 1967): 413-414.

Krammer, Arnold. "Islam and Nazi Germany's War." Journal of Military History, Vol. 79/2 (April 2015): 520-521.

Stein, Leon. "Nazi Propaganda for the Arab World by Jeffrey Herf." Shofar: An Interdisciplinary Journal of Jewish Studies, Vol. 30/2 (Winter 2012): 153-155.

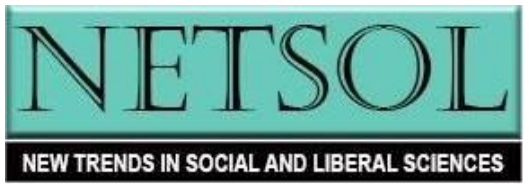

